\title{
PKM PADA PERANGKAT KELURAHAN DI KELURAHAN PANGOLOMBIAN KECAMATAN TOMOHON SELATAN KOTA TOMOHON
}

\author{
Theodorus Pangalila, Recky H. E. Sendouw \\ Fakultas Ilmu Sosial, Universitas Negeri Manado \\ E-mail : theopangalila@unima.ac.id
}

\begin{abstract}
ABSTRAK
Arus perubahan zaman yang semakin cepat membawa dampak yang positif dan negative dalam kehidupan masyarakat dan bangsa Indoensia. Akibat perubahan ini dan masuknya nilai-nilai asing turut mempengaruhi pemahaman masyarakat terhadap nilai-nilai Pancasila. Masyarakat kelurahan Pangolombian adalah masyarakat yang terbuka terhadap pengaruh nilai-nilai luar. Perangkat kelurahan merupakan agen perubahan dalam masyarakat. Lewat keberadaan mereka di tengah masyarakat perubahan masyarakat ke arah yang lebih baik dapat ditentukan. Mereka pula yang bertugas dalam mensosialisasikan nilai-nilai Pancasila kepada masyarakat di mana mereka berada. Namun permasalahan yang dihadapi adalah: (1). Semakin memudarnya pemahaman masyarakat tentang nilai-nilai Pancasila. (2). Kurangnya sosialisasi tentang nilai-nilai Pancasila kepada para perangkat kelurahan. Adapun dengan kegiatan ini para perangkat kelurahan di kelurahan Pangolombian Kecamatan Tomohon Selatan memperoleh pemahama tentang nilai-nilai dan mensosialisasikan tentang nilai-nilai Pancasila di tengah masyarakat. PKM menghasilkan luaran dalam bentuk artikel yang dipublikasikan dalam jurnal nasional.
\end{abstract}

\section{Kata Kunci: Perangkat kelurahan, nilai-nilai Pancasila}




\section{PENDAHULUAN}

Saiful Mujani dalam surveynya mengatakan bahwa 9,2 persen responden setuju NKRI diganti menjadi negara khilafah atau negara Islam. Hasil survey ini menunjukkan bahwa ada warga negara yang menginginkan dasar negara Pancasila diganti dengan dasar negara khilafah. Sementara itu hasil survei yang dilakukan Alvara, sebuah organisasi yang berbasis di Jakarta dan menjadikan 4.200 pelajar Muslim sebagai responden. Kebanyakan mereka ialah pelajar SMA dan mahasiswa di Pulau Jawa, pulau yang menampung lebih dari setengah populasi negara tersebut. Hasilnya, satu dari 10 pelajar mengaku mendukung sistem khilafah di Indonesia.

Beberapa data yang ditunjukkan oleh hasil survey di atas menunjukkan bahwa eksistensi Pancasila sebagai dasar negara telah mengalami pergeseran makna secara perlahan-lahan. Merebaknya kasus-kasus intoleransi di Indonesia saat ini menjadi indikasi nyata bahwa penghayatan terhadap esensi nilai-nilai Pancasila telah mengalami penurunan. Kasus-kasus penutupan gereja dan larangan beribadah bagi umat Kristiani, Katolik, Budha dan aliran kepercayaan lainnya mengindikasikan kurangnya pemahaman akan nilai-nilai Pancasila terutama sila pertama: Ketuhanan yang Maha Esa.

Permasalahan di lapangan yang dihadapi oleh masyarakat di kelurahan Pangolombian adalah persoalan melemahnya pemahaman masyarakat terutama generasi muda tentang nilai-nilai Pancasila. Sementara itu, para perangkat kelurahan yang merupakan agen perubahan dan perpanjangan tangan dari pemerintah daerah kurang pemahamannya tentang nilai-nilai Pancasila. Menurut Aziz Abdul Wahab (2011:181) pengimplementasian Pancasila dapat diklasifikasikan kedalam beberapa kelompok, sebagai berikut: (1).

Ada kelompok masyarakat yang tahu Pancasila dan mengamalkan dalam kehidupan sehari-hari. (2). Ada kelompok masyarakat yang tahu Pancasila tetapi tidak/belum mengamalkan dalam kehidupan sehari-hari. (3). Ada kelompok masyarakat yang tidak tahu Pancasila dan tidak/belum mengamalkan dalam kehidupan sehari-hari. (4). Ada kelompok masyarakat yang tidak tahu Pancasila tetapi mengamalkan dalam kehidupan sehari-hari.

Pancasila adalah warisan dari jenius Nusantara. Sesuai dengan karakteristik lingkungan alamnya, sebagai lautan yang ditaburi pulau-pulau (archipelago), jenius Nusantara juga merefleksikan sifat lautan. Sifat lautan adalah menyerap dan membersihkan, menyerap tanpa mengotori lingkungannya. Sifat lautan juga dalam keluasannya, mampu menampung segala keragaman jenis dan ukuran. Dengan ini, maka Pancasila merupakan kristalisasi nilai-nilai budaya local masyarkat Indonesia. Dalam Pancasila terkandung nilai-nilai luhur bangsa Indonesia yang menyatu dalam lima sila Pancasila [1].

Nilai-nilai Pancasila diakui memiliki keunggulan. Sejumlah ahli bahkan menyebutkan keunggulan Pancasila setara dengan ideologi-ideologi besar dunia, seperti Sosialisme, Marxisme dan lain-lain. Pancasila merupakan paduan unik antara moralitas agama dan naturalisme iptek, atau Barat yang sekuler dan Timur yang religius. Pancasila menyentuh dimensi lahir dan dimensi batin dari peradaban menusia. Artinya, manusia atau bangsa yang ingin maju dan kuat hendaknya memadukan nilai religius dengan iptek. Atau dengan kata lain, budaya dan peradaban akan berkembang menjadi unggul dan luhur bila didasarkan pada nilai-nilai moral agama dan ilmu pengetahuan/teknologi. Nilai-niai dasar dalam Pancasila haruslah dipahami sebagai satu kesatuan, artinya makna dan fungsi fundamental dari masing-masing nilai tidak saling terpisah, sebaliknya saling mengutuhkan satu sama lain, meski masing-masing sudah punya keunggulannya tersendiri. Namun kalau tidak dilakukan hal yang demikian, kita khawatir pemahaman parsial yang mungkin muncul akan membawa alam pikiran kita pada sikap pemujaan atau penolakan yang berlebihan terhadap Pancasila [2].

Sementara itu, Menurut Notonagoro [3] di dalam masing-masing sila Pancasila diketumukan esensi sebagai berikut:

- Ketuhanan sebagai esensi sila pertama

- Kemanusiaan sebagai esensi sila kedua

- Persatuan sebagai esensi sila ketiga

- Kerakyatan sebagai esensi sila keempat

- Keadila sebagai esensi sila kelima 
Nilai dasar "Ketuhanan Yang Maha Esa", bersama dengan nilai-nilai dasar yang lainnya membentuk satu kesatuan dasar Negara Republik Indonesia yang dikenal dengan Pancasila. Rumusan yang baik diberikan mengenai hal ini. Bagi negara dan bangsa Indonesia, nilai "Ketuhanan Yang Maha Esa" adalah sebagai landasan atau acuan spiritual dalam kehidupan bermasyarakat dan bernegara. Nilai "Kemanusiaan Yang Adil dan Beradab", sebagai landasan moral dan etiknya. Sila "Persatuan Indonesia" sebagai acuan sosialnya, dan "Kerakyatan yang Dipimpin oleh Hikman Kebijaksanaan dalam Permusyawaratan Perwakilan", sebagai acuan politiknya, sementara "Keadilan Sosial bagi Seluruh Rakyat Indonesia", sebagai tujuan bersama dalam bernegara yang harus diwujudkan [2].

Mengingat kompleksnya permasalahan tersebut di atas dan disadari bahwa tidak semua permasalahan dapat diselesaikan sekaligus dalam kurun waktu tertentu maka berdasarkan justifikasi dan kesepakatan bersama dengan masyarakat mitra maka dipilih beberapa permasalahan prioritas yang harus diatasi, yaitu:

Mitra 1:

- Semakin memudarnya pemahaman masyarakat tentang nilai-nilai Pancasila.

- Kurangnya sosialisasi tentang nilainilai Pancasila kepada para perangkat kelurahan.

- Solusi yang ditawarkan dalam kegiatan ini adalah kegiatan penguatan nilai-nilai Pancasila bagi para perangkat kelurahan di Kelurahan Pangolombian Kecamatan Tomohon Selatan.

\section{TARGET LUARAN}

Luaran dalam kegiatan PKM ini ditargetkan adalah sebagai berikut:

a. Sosialisasi kepada perangkat Kelurahan Pangolombian tentang nilai-nilai Pancasila.

b. Pelatihan tentang cara mensosialisasikan nilai-nilai Pancasila kepada masyarakat umum.

c. Laporan kegiatan dan artikel untuk dipublikasikan dalam Jurnal nasional.

\section{METODE PELAKSANAAN}

Bertolak dari permasalahan tentang kurangnya sosialisasi tentang nilai-nilai Pancasila kepada perangkat kelurahan Pangolombian, maka bersama kelompok mitra dan untuk menjawab permasalahan pertama; Semakin memudarnya pemahaman masyarakat tentang nilai-nilai Pancasila. Masalah ini akan diatasi dengan bekerjasama dengan pemerintah kelurahan untuk melakukan tindakan-tindakan kongkrit berupa:

a. Mengumpulkan seluruh perangkat kelurahan.

b. Melakukan tes singkat tentang pemahaman perangkat kelurahan tentang nilai-nilai Pancasila

c. Bersama pemerintah kelurahan mensosialisasikan kepada perangkat kelurahan tentang pentingnya pemahaman terhadap nilai-nilai Pancasila.

Setelah adanya kesamaan persepsi antara pemerintah kelurahan Pangolombian dan para perangkat kelurahannya, maka selanjutnya akan diadakan pelatihan dan pendampingan dalam bentuk sosialiasi.

Permasalahan kedua, Kurangnya sosialisasi tentang nilai-nilai Pancasila kepada para perangkat kelurahan. Setelah masalah pertama selesai dan proses pendampingan kepada para perangkat kelurahan selesai, maka selanjutnya akan diberikan pembekalan bagaimana teknik dan cara mensosialisasikan tentang nilainilai Pancasila pada masyarakat kelurahan Pangolombian.

Kegiatan dilaksanakan dalam bentuk ceramah, diskusi, dan praktek lapangan. Metode ceramah dan diskusi digunakan dalam mentransfer ilmu tentang pentingnya pemahaman perangkat kelurahan serta masyarakat tentang nilainilai Pancasila. Kemudian juga akan dijelaskan tentang bagaimana cara yang tepat untuk mensosialisasikan tentang nilai-nilai Pancasila kepada masyarakat.

Langkah yang akan dilakukan oleh tim kerja pelaksana PKM adalah melakukan persiapan yang diawali dengan pembahasan program dan langkah-langkah kerja tim mulai dari pembagian tugas dan tanggungjawab masing-masing anggota tim sampai dengan persiapan administrasi 
dan perangkat pendukung. Kegiatan lain yang masuk dalam persiapan adalah melakukan koordinasi dengan Lurah dan perangkat kelurahan untuk menyampaikan rencana pelaksanaan kegiatan PKM. Persiapan selanjutnya secara bersama tim kerja menyusun draft instrumen yang akan digunakan sebagai acuan dalam menjaring informasi atau data akurat tentang permasalahan mendasar mitra. Dengan demikian Instrumen yang disusun mencakup identifikasi atau penjaringan informasi permasalahan mendasar yang harus dipahami secara bersama sebelum mengawali kegiatan PKM ini antara lain adalah mengidentifikasi dan mempertajam serta menganalisis kembali faktor-faktor penyebab kedua permasalahan pokok di atas, juga mendapatkan informasi dan persepsi para para perangkat kelurahan di Kelurahan Pangolombian mengenai permasalahan dan akar permasalahan yang dihadapi serta program yang ditawarkan dan langkah yang akan dilakukan untuk mengatasi permasalahan terutama yang berkaitan dengan upaya mengatasi permasalahan kurangnya pemahaman mereka tentang nilai-nilai Pancasila. Hasil identifikasi tersebut di samping menjadi dasar penyusunan rencana kerja sekaligus sebagai landasan pelaksanaan kegiatan PKM. Langkah persiapan yang lainnya adalah pemantapan pemahaman atau penyamaan persepsi tentang program yang akan dijalankan oleh tim itu sendiri serta persiapan dan pengadaan materi yang akan digunakan dalam pelaksanaan kegiatan PKM.

Pelaksanaan kegiatan PKM pada masyarakat ini rencananya akan dilaksanakan selama 1 bulan, namun jika hasil kegiatan belum menampakkan hasil yang signifikan, maka akan dilanjutkan dengan kegiatan tambahan untuk lebih memantapkan hasil PKM.

\section{HASIL PENELITIAN DAN PEMBAHASAN}

Pelaksanaan kegiatan PKM pada pada perangkat Kelurahan di Kelurahan Pangolombian Kecamatan Tomohon Selatan Kota Tomohon dengan bentuk kegiatan "Penyuluhan Pada Perangkat Kelurahan di Kelurahan Pangolombian Kecamatan Tomohon Selatan Kota
Tomohon sudah berjalan dengan baik. Berikut ini penjelasan hasil kegiatan PKM yang dituangkan dalam bentuk hasil kegiatan sebagai berikut:

\section{Hasil Kegiatan \\ Perencanaan}

Kegiatan-kegiatan yang dilakukan pada tahap perencanaan bisa dideskripsikan sebagai berikut:

a. Pembahasan Program Kegiatan

Persiapan yang diawali dengan pembahasan program dan langkah-langkah kerja tim mulai dari pembagian tugas dan tanggungjawab masing-masing anggota tim sampai dengan persiapan administrasi dan perangkat pendukung. Kegiatan lain yang masuk dalam persiapan adalah melakukan koordinasi dengan kepaka sekolah untuk menyampaikan rencana pelaksanaan kegiatan PKM. Kegiatan pembahasan program ini dilaksanakan pada bulan Februari 2019 sekaligus pelaksanaan KKN Unima Gelombang 1 Tahun 2019 di Kelurahan Pangolombian. Pada kesempatan ini tim pelaksana dan mahasiswa KKN Unima bertemu dengan Lurah Kelurahan Pangolombian beserta perangkat kelurahan untuk meminta persetujuan tentang kegiatan PKM yang akan dilaksanakan. Setelah disetujui kemudian tim menjelaskan secara rinci maksud dan tujuan pelaksanaan PKM Pada Perangkat Kelurahan di Kelurahan Pangolombian Kecamatan Tomohon Selatan Kota Tomohon.

\section{b. Penyusunan Draft Instrumen}

Persiapan selanjutnya secara bersama tim kerja menyusun draft instrumen yang akan digunakan sebagai acuan dalam menjaring informasi atau data akurat tentang permasalahan mendasar mitra. Kegiatan ini dilaksanakan pada bulan Maret 2019. Instrumen yang disusun mencakup identifikasi atau penjaringan informasi permasalahan mendasar yang harus dipahami secara bersama sebelum mengawali kegiatan PKM ini antara lain adalah mengidentifikasi dan mempertajam serta menganalisis kembali faktor-faktor penyebab kedua permasalahan pokok di atas, juga mendapatkan informasi dan persepsi para perangkat kelurahan di 
Kelurahan Pangolombian Kecamatan Tomohon Selatan Kota Tomohon mengenai permasalahan dan akar permasalahan yang dihadapi serta program yang ditawarkan dan langkah yang akan dilakukan untuk mengatasi permasalahan terutama yang berkaitan dengan upaya mengatasi permasalahan semakin memudarnya pemahaman generasi muda tentang nilainilai Pancasila. Hasil identifikasi tersebut di samping menjadi dasar penyusunan rencana kerja sekaligus sebagai landasan pelaksanaan kegiatan PKM.

\section{c. Penyusunan Program Pelatihan}

Berdasarkan hasil indentifikasi tentan permasalahan yang ada di lapangan selanjutnya disusun program pelatihan. Dalam kegiatan ini dilakukan pemantapan pemahaman atau penyamaan persepsi tentang program yang akan dijalankan oleh tim itu sendiri dengan seluruh perangkat kelurahan, lurahan dan mahasiswa peserta KKN Unima Gelombang 1 Tahun 2019 serta persiapan dan pengadaan materi yang akan digunakan dalam pelaksanaan kegiatan PKM.

\section{Pelaksanaan Kegiatan}

Pelaksanaan kegiatan PKM dilaksanakan selama dua hari, yakni tanggal 15-16 Maret 2019. Hari pertama, tanggal 15 Maret kegiatan difokuskan pada pemberian materi tentang hasil-hasil survey dan data tentang pemahaman masyarakat Indonesia tentang nilai-nilai Pancasila dan permasalahannya. Kegaitan ini dihadiri oleh 23 orang perangkat kelurahan serta mahasiwa peserta KKN di Kelurahan Pangolombian. Untuk sesi pertama disajikan dan dijelaskan tentang Pancasila dan nilai-nilai yang terkandung di dalamnya. Setelah itu para peserta diberikan waktu untuk istirahat. Selanjutnya dalam sesi kedua dijelaskan tentang bagaimana cara mensosialisasikan tentang nilai-nilai Pancasila kepada generasi muda dan masyarakat pada umumnya. Dalam kegiatan hari pertama ini para peserta kelihatan begitu antusias dalam mengikuti setiap materi yang disajikan.

Pelaksanaan kegiatan hari kedua dilaksanakan pada tanggal 16 Maret 2019. Kegiatan PKM pada hari kedua difokuskan pada penjelasan dan penguatan tentang peran masyarakat, perangkat kelurahan dan pemerintah kelurahan dalam penguatan nilai-nilai Pancasila kepada generasi muda dan kepada seluruh masyarakat di kelurahan Pangolombian Kecamatan Tomohon Selatan Kota Tomohon.

\section{Observasi dan Evaluasi}

Kegiatan selanjutnya yang dilakukan tim PKM adalah melakukan observasi dan evaluasi. Observasi dilakukan tim terhadap seluruh proses kegiatan mencakup proses pemberian materi dan bagaimana pemahaman perangkat kelurahan Pangolombian Tomohon Selatan terhadap materi-materi pelatihan yang sudah diberikan. Hal-hal pokok lainnya yang diobservasi oleh team adalah kendalakendala dan kesulitan-kesulitan yang dihadapi oleh perangkat kelurahan dan pemerintah kelurahan Pangolombian dalam mensosialisakan tentang nilai-nilai Pancasila.

Evaluasi dilakukan oleh tim terhadap bagaimana proses sosialisasi tentang nilainilai Pancasila kepada generasi dan masyarakat di Kelurahan Pangolombian Kecamatan Tomohon Selatan. Evaluasi dilakukan dengan berdasarkan hasil observasi yang telah dilakukan oleh tim. Dari hasil evaluasi tersebut kemudian oleh tim diberikan masukan dan koreksi terhadap hal-hal yang dianggap masih kurang dipahami oleh para perangkat kelurahan yang ada di Kelurahan Pangolombian Kecamatan Tomohon Selatan Kota Tomohon.

\section{Refleksi}

Refleksi dalam kegiatan PKM pada perangkat kelurahan di Kelurahan Pangolombian Kecamatan Tomohon Selatan ini dilakukan dengan tujuan untuk mengetahui kelebihan dan kekurangan yang muncul dalam proses pelaksanaan kegiatan ini. Hal ini dilakukan untuk menemukan rekomendasi yang cocok bagi pengembangan kegiatan selanjutnya. Hasil refleksi menjadi penting, karena lewat refleksi hasil kegiatan, para perangkat kelurahan menyadari kekurangan dan kelebihannya masing-masing dan berusaha memperbaiki dalam proses kegiatan selanjutnya. 


\section{KESIMPULAN}

Hasil yang dicapai melalui kegiatan PKM Pada Perangkat Kelurahan di Kelurahan Pangolombian Kecamatan Tomohon Selatan Kota Tomohon bisa disimpulkan sebagai berikut:

1. Ada antusias yang tinggi dari para perangkat kelurahan dan pemerintah kelurahan Pangolombian dalam upaya menanamkan nilai-nilai Pancasila kepada generasi muda dan masyarakat pada umumnya.

2. Terdapat peningkatan pemahanan dan kesadaran akan pentingnya pemahaman terhadap nilai-nilai Pancasila yang merupakan pedoman dalam hidup bermasyarakat.

\section{REFERENSI}

Y. Latif, Negara Paripurna: Historisitas, Rasionalisme, dan Aktualisasi Pancasila. Jakarta: Gramedia, 2011.

L. H. Saifuddin, "Revitalisasi Nilai-Nilai Pancasila dalam Perspektif UUD 1945,” 2012. [Online]. Available: http://lukmansaifuddin.com/index.p hp?option-revitalisasi-nilai-nilaipancasila-dalam-perspektif-uud1945.

Notonagoro, Pancasila Secara Ilmiah Populer. Jakarta: Pantjuran, 1975. 